\title{
Modern Dreamers
}

\section{ELUNED SUMMERs-BREMNER}

UNIVERSITY OF AUCKLAND

\author{
Helen Groth and Natalya Lusty \\ Dreams and Modernity: A Cultural History \\ Routledge, Abingdon and New York, 2013 \\ ISBN 9780415606950 RRP AUD\$50.97
}

This welcome co-authored book, published in 2013, provides a historical overview of the ways the work of the pioneers and elaborators of dream science-a field made up of several interconnecting subfields-was taken up by ordinary citizens curious not only about the import but also the structural operations of their dreams. Helen Groth and Natalya Lusty begin their survey in the early to mid nineteenth century, the point of inception of the concerted study of dreams, and conclude with an account of the mid twentieth-century, wartime experiment in documenting dreams performed by the research group Mass Observation (M0). Dreams and Modernity is clearly the product of a carefully delineated research plan, and its analyses and arguments are thought provoking and persuasive. Both authors write in a lucid, accessible style that should make the book useful to a range of scholars and interested readers both within and beyond its several fields. One of the volume's ISSN 1837-8692

Cultural Studies Review 2015. @ 2015 Eluned Summers-Bremner. This is an Open Access article distributed under the terms of the Creative Commons Attribution 4.0 Unported (CC BY 4.0) License (https://creativecommons.org/licenses/by/4.0/), allowing third parties to copy and redistribute the material in any medium or format and to remix, transform, and build upon the material for any purpose, even commercially, provided the original work is properly cited and states its license. 
strengths, and a likely source of appeal to those working in cultural history and the history of science and psychology in particular, is its assiduous charting of the process whereby both popular and medico-scientific interest in dreams follow the principles by which dreams appear to function themselves.

For instance, the opening chapter discusses the work of Robert Macnish, Walter Cooper Dendy and John Addington Symonds, which shows anxiety and excitement in equal measure. These writers and physicians urge the public to take dreams seriously but are troubled by both the intrinsic loss of mastery inherent in dreaming and the threat to scientific mastery that investigating dreams involves. As the authors note, unprecedented discoveries in the early nineteenth century about the nature and operation of the mind and brain emerged in the wake of political upheavals of significant magnitude in Europe: the events of the French Revolution and the Napoleonic wars. The miscellany style in which the work of these three writers is disseminated reflects the social and political challenges of these years. Wars and revolutions are themselves phantasmagoric, both in their ungraspable scale and their tendency to evince fragmentation, a fragmentation paradoxically often underwritten by larger, simpler slogans and aims. The work of both physician writers and the authors of popular dream guides in this period suggest points of origin for dreams that cannot be definitively proven, and the question of what causes dreams comes to be aligned with the question of when political conflicts and large scale social changes begin. We dream, perhaps, because we cannot fully manage the lives we live. And we have wars because we have never fully managed to balance the combination of personal desire and sacrifice that living well with our fellow human beings entails.

Accordingly, the book's next chapter considers how the writings of Frances Power Cobbe, George Henry Lewes and James Sully map out systems for understanding the mind-brain relationship, the nature of cognition and consciousness and the extent to which we are morally responsible for our dreams. Cobbe's essays on unconscious cerebration, the state in which, according to her friend William Carpenter, cognition occurs while the will is suspended, develop correspondences between the acts of reading, writing and dreaming. On these occasions, in Cobbe's view, we practise a form of double consciousness in which one part of the mind synthesises while the other engages with individual components of 
perception such as images and words. Lewes, meanwhile, drawing on the work of evolutionary psychologist Herbert Spencer, develops the idea that the apparent unity of consciousness is sustained by differentiations in its state. For James Sully, dreams are repositories of continuous aspects of our being that we cannot retain consciously while we encounter new phenomena as our everyday experience requires.

The work undertaken by the Society for Psychical Research, founded by Frederick Myers, Frank Podmore and Ivor Gurney in 1882, was designed to develop ways of accounting for the complexities of the process engaged in by individual dreamers but more importantly to explore how some of the intrinsic difficulties of studying dreams might be resolved. In many Western societies at least, each dreamer is the sole source of information regarding the content and nature of his or her dreams. Yet through a collaborative process which incorporated correspondence with dreamers from as far afield as India and Australia, Myers and Gurney devised a method for testing the usefulness and veracity of dream recollection. Privileging intense dreams caused by unusual events, the authors of Phantasms of the Living (1886) interviewed the dreamer and independent witnesses in order to arrive at a working account of the possible causes of a dream. As Groth and Lusty indicate, Myers's positing of the existence of a 'subliminal self' to explain the variety of experiences recalled by dreamers influenced William James and Henri Bergson, both of whom took a keen interest in the society's work. Myers' 'Subliminal Self' is a kind of collective resource pool of human thought and experience on which, for Bergson as for Freud, the dreaming mind draws, taking from the sum of unnoticed quotidian moments material with which to create new scenes.

The book's second half begins with the English reception of Freud's Dream Book of 1899, focusing usefully on the relatively underexplored connections between Freud's work on trauma and that which William Brown and W. H. R. Rivers carried out with traumatised combatants of World War I. This chapter does a creditable job of presenting early twentieth-century English psychology's main points of agreement with, and departure from, Freud's ideas about how dreams function. It is important to avoid allowing Freud to dominate discussion in a book that is as much about the reception, professional and otherwise, of medical and other scientific theories about dreams as about the production of expert surmises. 
Nonetheless, this part of the book could have been sharpened by a better understanding of sexual repression. When sexual impulses are understood as the mere culturally operative means by which Freud discerns a process of historical displacement along a chain of elements in suffering patients who are also dreamers, it is plain that there is no substantial point of conflict with the work of Rivers. Affect is given primacy in Freud's accounts of dreams to the precise extent that it serves as the continuous element between two otherwise mutually exclusive interfaces of the mind. Symbolic meaning can be displaced along a chain of associations potentially ad infinitum, but traumatically generated affect cannot.

The chapter on Surrealism and the work of Walter Benjamin extends the Freudian focus on the dream as a carrier of overdetermined historical processes that drive modernity. The 'affective intensity and ordinariness' of the dream, coupled with its 'hermeneutic obscurity', (114) becomes, with the advance of industrial and consumer capitalism, a means by which those affected by these large scale, frequently brutal processes can understand the nature of their experience. For most people in the West and some Westernised parts of the world in the years between World War I and World War II, as for many since, modernity simply is the loss of individual volition amid fragmentary image-complexes offering more possibilities than can be inhabited or allowed. Modernity is dreamlike, in other words, and dreams have the role of playing back to people, in imperspicuous form, some of the more unmanageable, suprarationalised aspects of their lives.

Yet it is in the theatre of war and, more specifically, in the material inversion of almost all the propensities of civilian life that characterised the World War I battlefront that artistically experimental programs like those of the Surrealists find their original mode of operation. While the Surrealists explicitly modelled their publicly generated information and image gathering on the phenomenon of social revolution, in which many components of a given social order change, Walter Benjamin's Arcades Project and other writings extend this interest in social critique to engage directly with one of the more fundamental features of early to mid twentieth-century European capitalism: its tendency to displace objects from the realm of the everyday by suffusing them with the tantalising properties of dreams. It is useful to be reminded of the link between the European avant-garde, Benjamin and the work of Mass Observation because World War II, in which the focus of 
conflict was, for the first time, split equally between civilian and combatant zones, provided one of the most fertile grounds for experimental artistic work, accompanied by some of the least favourable conditions for its production. In this context, Mass Observation offered to ordinary Britons the opportunity to become not only social observers but agents of the constitution of the country's rapidly altering self-image. A small but significant number were also professional writers themselves.

As James Hamilton has made clear to us, the people who volunteered to write for MO were, almost by definition, non-representative of what was thought by the governing and media powers of the day to constitute the 'common mass' of people. Groth and Lusty's focus on individual dreamers is therefore welcome, and there is good coverage of the range of dreams and reflections on them offered by respondents, as well as an indication of the range of respondents' knowledge of professional dream theory. It is also worth noting that the accounts of their dreams, and their conjectures about them, that observers sent to the archive served the further purpose of documenting the civilian war's fantastical-even hallucinatoryproperties, in indirect as well as more obvious ways. If researchers have not always found the dreams themselves particularly revealing, this may indicate that dreams can change, not only according to whether or not a dreamer is giving them thoughtful attention but also in relation to how disturbingly unreal civilian lives can be in wartime as in other periods of cultural transition and upheaval.

Eluned Summers-Bremner is a senior lecturer in English at the University of Auckland, New Zealand. The author of Insomnia: A Cultural History (2008) and A History of Wandering (forthcoming), she is currently working on a history of the sea and human emotions for Reaktion, and on the literature of World War II. 